\title{
The atmospherical drought as a decisive factor of yield in the main sour cherry varieties of Hungary
}

\author{
Lakatos, L. ${ }_{\bullet}$, Szabó, T. ${ }^{2}$, Soltész, M. ${ }^{3}$, Szabó, Z. ${ }^{3}$, Sun, Z. ${ }^{4} \&$ Nyéki, J. ${ }^{3}$ \\ ${ }^{1}$ University of Debrecen, Centre of Agricultural and Applied Economic Sciences, Department of Agricultural \\ Engeneering H-4032 Debrecen, Böszörményi 138, Hungary, lakatos@agr.unideb.hu \\ ${ }^{2}$ Fruit Growing Research and Extension Institute H-4244 Újfehértó Vadastag 2.,Hungary \\ ${ }^{3}$ University of Debrecen, Institute of Horticulture, H-4032 Debrecen, Böszörményi 138, Hungary \\ ${ }^{4}$ Inst. of Environment and Development in Agriculture (IEDA), Chinese Academy of Agricultural Sciences (CAAS), \\ No. 12, Zhong-guan-cun South Street Beijing 100081 P.R. China
}

\begin{abstract}
Summary: Atmospheric drought causes heavy difficulties of water supply in most fruit species grown in Hungary, although the modern, intensive plantations are already equipped with irrigation. The use a dripping systems are widely applied, therefore nothing was done to avert the risk of atmospheric drought. In excessively dry seasons the reduction of yields is often due to atmospheric drought. Present study aims to utilise measured data of meteorological parameters (relative air humidity and temperature) to develop an index to characterise drought and measure its effect on fruit yield. Causes influencing yields are multiple. Phytosanitary problems are combined with deficits of water supply. Water deficit of the soil is avoided by dripping irrigation, but the atmosphere is influenced by sprinklers only. Atmospherical drought increases the transpiration of the trees intensely and causes reduction of photosynthetic activity, consequently impairs the yield.

Applying the index developed in a plantation of 6 sour cherry varieties grown in Hungary (Meteor, Nefris, Pándy, Újfehértói fürtös, Kántorjánosi, Debreceni bőtermő), we measured the specific yields (yield per volume of tree crown) during the period 1989-2011 using the meteorological database of the growing site. Additionally, other parameters characterising the drought are compared and searched for a method most reliable for judging the specific yielding capacity of sour cherry varieties.

The results proved convincingly the utility of the index, especially for the varieties Pándy and Újfehértói fürtös. Comparison with other indices expressing the effects of drought revealed the superiority of our index, which will be applied in the future to express the risk of atmospheric drought.
\end{abstract}

Key words: atmospherical drought, sour cherry, fruit yield, dripping irrigation, sprinkler irrigation, LSZI index

\section{Introduction and survey of the literature}

The occurrence of drought during the growing period is a well known phenomenon under Hungarian climatic conditions. The numerical expression of damages caused by drought has been attempted by indices of Antal-Glantz (1988). The indices are aiming to exploit meteorological and hydrological parameters to describe the effects of drought on the development of cultivated plants. Studies of Varga-Haszonits (1989), Nemes (1993), Simon (1993) dealt with the feasibility of drought indices, which show close relation with the decline of yields. Water requirement, water-uptake, water utilisation being species- (or even variety-) specific properties of plants, we have to apply the individual indices to the right object.

An important decision is to actualise the purpose of the index. If we would like to evaluate the last year's or season's history by means of the data registered, the only absolute condition is the existence of data for calculating the indices required.
However, if the policy of planning interventions to avoid damages is actual, as to secure optimal conditions regarding supply of water, we need indices easily compounded from instantly produced but reliable measurements.

Most of the indices designed for the agricultural practice require several parameters, which are difficult to be produced. The drought index of Palmer (1965) is widely recognised, but the determination of components necessary to calculate water husbandry (the CAFEC value) is rather complicated as indicated by Faragó et al. (1989).

Besides the reliability of the index, the operative prevention of drought damage needs instantaneous accessibility of the operator horticulturist. Nowadays, most fruit and vegetable growers invested to dripping irrigation. The optimal water content of the soil is kept successfully, all the same, symptoms of drought appeared. We are interested to find the reasons of that phenomenon, the way to avoid damages, i.e. decline of yield, caused by atmospheric drought. 
We supposed that atmospheric drought impairs the balance of water circulation in the plant. Physiological changes may cause necrosis of some organs or even of whole plants. Some low water content does not mean water stress as far as the temperature is low. Similarly, high temperatures damage the plant unless the air humidity is low.

\section{Material and method}

The community Újfehértó belongs to the geographic region of Nyírség, as determined by its relief and soil relations. The typical soil is sand with some humus content, and as East-European brown forest and meadow soil. The surface of Research Station is slightly wavy, depressions of different size are typical. The carbonate content is low and the upper humous layer is $60 \mathrm{~cm}$. The ground water level is around $250 \mathrm{~cm}$ deep. Conditions are favourable to develop atmospheric drought

The sour cherry varieties on the Research Station of Újfehértó were planted and cultivated by the same system (density, form of crown, cultivation, phytosanitary treatments).

Atmospheric drought has been defined always when the temperature was more than $25^{\circ} \mathrm{C}$ and relative humidity of the air was less than $40 \%$. More severe conditions have been also defined, but we kept to the "soft" alternative as a condition of higher frequency (918) to be observed during the period between March and October.

The 918 events were monthly distributed as explained below:

During the past 47 years, the majority (17\%) was registered in July, then August (16\%) and June (12\%) followed, as atmospheric drought ensued.

In the present study, the parameter of drought was calculated according to Karácsonyi (1994), which means multiplicative combination of temperature and water content data. We suppose that if temperature maxima trespass $25^{\circ} \mathrm{C}$ and relative humidity was less than $40 \%$, the transpiration of the fruit species of moderate climate, increases conspicuously. At the same time, if the water capacity of the soil sank below $75 \%$, the water uptake of the plant is impaired. The hydric (water) balance of the plants collapses. Physiological anomalities appear, and as a consequence, some parts or even the whole plant may die.

At high temperatures, higher than $30^{\circ} \mathrm{C}$ maxima still did not harm the plants at higher air humidity (50-60\%), and no signs of utter transpiration appear. No harm was observed on the plants at $30 \%$ relative air humidity unless the temperature was between 10 and $15^{\circ} \mathrm{C}$.

The function to be calculated is:

$$
L S Z I=\frac{\bar{T}}{25} * \frac{40}{R T_{13 h}}
$$

(Formula 1.a)

Where $\mathrm{T}$ is the daily mean temperature,

$\mathrm{RT}_{13 \mathrm{~h}}$ is the relative air humidity measured at 13 hours (1 PM)
If the product of the formula (index) is higher than 1, atmospheric drought is recognised.

The interval $0.0<\mathrm{LSZI}<0.5$ means favourable water supply $0.5<\mathrm{LSZI}<1.0$ sufficient water supply

$1.0<\mathrm{LSZI}<1.5$ moderate water stress, insufficient supply

$1.5<\mathrm{LSZI}<2.0$ strong atmospheric drought, heavy difficulties with water supply

$2.0<\mathrm{LSZI}<2.5$ heavy atmospheric drought, water uptake system collapsed

$2.5<\mathrm{LSZI}<3.0$ extremely heavy atmospheric drought, irreversible damages of stress

The value of the index changes continuously during the growing season between 0 and 3. Signs of water stress appear when the value of the index higher than 1 . The necessity of intervention depends on the plant species or variety, on the age, stage of development, nevertheless on the water supply of the soil too.

It's generally accepted that with the value of the index

The utility of the index is well founded by the simplicity and ease of computing it and to make decisions instantly.

This index has been tested earlier on field crops by computing predictions of mean yields on the level of regional units. It was stated that it is useful to estimate yields before harvest on the basis of recognising atmospheric drought (Lakatos et. al 2005). The present study shows an attempt to estimate yields of fruit plantations by means of measuring the intensity of atmospheric drought. At the same time, there was an opportunity to use the present database to compare alternative indices recommended by different authors, which estimates were most approaching the truth measured. On a matrix of correlations between yields and the indices computed are already published for a number of cultures in Hungary by Varga-Haszonits (1989) and Nemes (1993) and proved the utility of the method.

During the last years, the time of bloom and maturity in sour cherries was variable but we did not consider that moment instead took an average year and considered the period between April 1 and July 31 computing the indices for each day.

The comparison ensued with the following alternative indices:

LSZI the atmospheric drought index.

The drought index of Pálfai: PAI (Pálfai, 1993)

$$
P A I=\frac{t_{I V-V I I I}}{P_{X-V I I I}} k_{t} k_{P} k_{g w}
$$

Where PAI is the drought index ${ }^{\circ} \mathrm{C} / 100 \mathrm{~mm}$;

$\mathrm{t}_{\mathrm{IV}-\mathrm{VIII}}$ is the mean temperature of the period between April and August;

$\mathrm{P}_{\mathrm{X}-\mathrm{VIII}}$ is the weighted sum of precipitation $(\mathrm{mm})$ between October and August;

$\mathrm{k}_{\mathrm{t}}, \mathrm{k}_{\mathrm{p}}, \mathrm{k}_{\mathrm{gw}}$ are temperature, precipitation and correction factor for soil humidity (computed according to Bussay et. al (1999)). 
Standardised index for anomalies of precipitation; SPAI (Faragó et al. 1988)

$$
S P A I=\frac{P-\bar{P}}{\sigma_{p}}
$$

Where $\mathrm{P}$ is the sum of precipitation, $\bar{P}$ is the mean precipitation of many years,

$\sigma_{p}$ is the variation of precipitations. The negative values of

the index signalise the possibility of drought.

Hydrometric index of Szeljanyinov HTC

$$
H T C=\frac{P}{0,1 \sum t} \quad\left[m m /{ }^{\circ} \mathrm{C}\right]
$$

Where $\mathrm{P}$ is the sum of precipitation, $\sum t$ is the active mean temperature computed from the daily mean temperatures ${ }^{\circ} \mathrm{C}$

Climatic water balance (Index of water supply); P-PET

$\mathrm{P}$ is the sum of precipitation of the period, PET is the potential evapotranspiration computed according to Antal (1968), Szász (1973)

Drought index; PET/P

$\mathrm{P}$ is the sum of precipitation of the period, PET is the potential evapotransspiration computed according to Antal (1968) and Szász (1973)

Ratio of evaporation; TET/PET

The potential evaporation (PET) is computed according to Antal (1969) and Szász (1973), and the effective evaporation (TET) computed according to Varga-Haszonits, Tölgyesi (1990).

Relative soil humidity; $\mathrm{RTN}=\mathrm{TN} / \mathrm{WK}_{\min }$

where TN is the water reserve of the upper $1 \mathrm{~m}$ deep soil layer (segment) expressed in mm.,

$\mathrm{WK}_{\min }$ is the minimal water capacity of the same soil layer, which was in our case $280 \mathrm{~mm}$.

\section{Results}

Earlier studies (Lakatos et. al 2005) suggested that the meticulous refinement or weighting of the index signalising atmospheric drought would make our estimates more precise as for the yields expected. The method of weighting could follow alternatives. We may apply a correction factor for relative humidity as proposed by Pálfai (1999):

$$
K R N=\sqrt[5]{\frac{n+1}{n+1}}, \text { where } \mathrm{n} \text { is the number of days with }
$$

low relative air humidity $(\mathrm{RN}<30 \%)$ during the growth period, $n$ is the mean number (of many years) with low relative air humidity

$$
L S Z I=\frac{\bar{T}}{25} * \frac{40}{R T_{13 h}} * \mathrm{KRN}
$$

(Formula 1.b)

According to Formula 1.b, the relative air humidity is taken to correct the value of the index, and the extremely deleterious changes of air humidity are indicated more precisely. The data of yields during the last 23 years facilitated the composition of a matrix of correlation coefficients:

In Table 1, the fruit growing region of Újfehértó the LSZI indices show the relation between drought and yields. The index is particularly fitting for the sour cherry varieties Pándy and Újfehértói fürtös. As a good alternative index were the TET/PET ratio (for the variety Kántorjánosi this fitted the best), relative soil humidity (RTN) and the standardised anomaly of precipitation index, the SPAI.

Averages of atmospheric drought for the whole growing

\begin{tabular}{|c|c|c|c|c|c|c|c|c|}
\hline Varieties & LSZI & Pálfai & SPAI & Szeljanyinov & p-PET & PET/P & TET/PET & RTN \\
\hline METEOR & -0.39 & 0.00 & -0.37 & -0.35 & -0.39 & 0.11 & 0.05 & 0.01 \\
\hline NEFRIS & -0.35 & -0.28 & -0.21 & -0.25 & -0.25 & 0.00 & -0.15 & -0.11 \\
\hline PÁNDY & -0.87 & -0.88 & -0.67 & -0.63 & -0.66 & 0.61 & -0.67 & -0.61 \\
\hline ÚJFEHÉRTÓI FÜRTÖS & -0.55 & -0.48 & -0.47 & -0.43 & -0.37 & 0.11 & -0.45 & -0.48 \\
\hline KÁNTORJÁNOSI & -0.21 & 0.20 & -0.09 & -0.03 & 0.04 & -0.19 & -0.38 & -0.39 \\
\hline DEBRECENI BŐTERMŐ & -0.42 & -0.37 & -0.23 & -0.19 & -0.14 & -0.10 & -0.40 & -0.41 \\
\hline MEAN & 0.47 & 0.37 & 0.34 & 0.31 & 0.31 & 0.19 & 0.35 & 0.34 \\
\hline
\end{tabular}
season during a 23 year-long period varied between 0.2 and

Table 1 - The correlation between the main indices of drought and the yields of sour cherry varieties (Újfehértó, 1964-2011) 
1. The characterisation of the whole season was not possible by means of the scale applied for mark one day's drought, therefore another system of signs has been introduced:

$0.0<\mathrm{LSZI}<0.2$ good water supply

$0.2<\mathrm{LSZI}<0.4$ sufficient supply

$0.4<\mathrm{LSZI}<0.6$ moderately insufficient, staggering water supply

$0.6<\mathrm{LSZI}<0.8$ strong atmospheric drought with serious problems in water supply $0.8<\mathrm{LSZI}<1.0$ heavy atmospheric drought, collapse of the water provision system

1.0<LSZI extreme atmospheric drought with necrosis, irreversible damages.

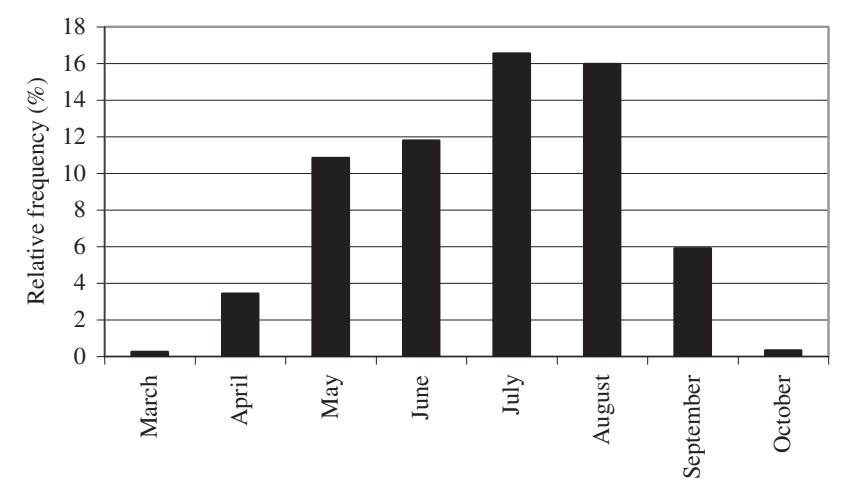

Figure 1 - The frequency of atmospheric drought found at Újfehértó(1964-2011)

The seasonal average of indices of atmospheric drought and its relation with the fruit yields of the variety Újfehértói fürtös (Figure 2) indicate clearly the significance of drought as a component of yield.

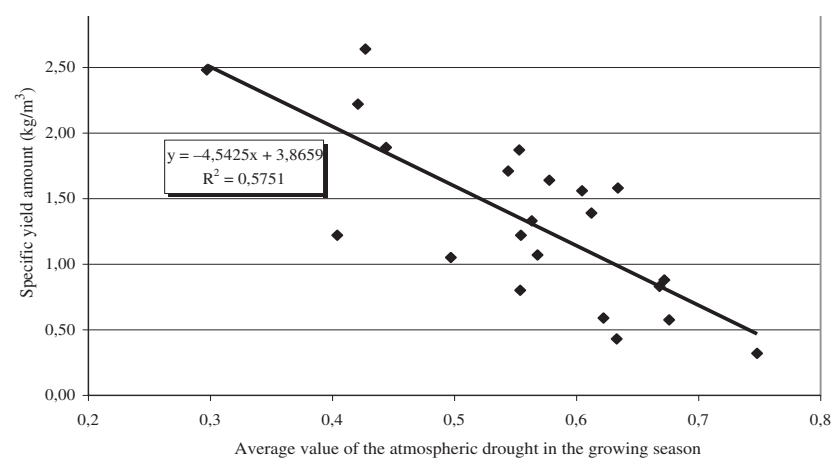

Figure 2 - Correlation between the specific yield of the sour cherry variety Újfehértói fürtös and the index of atmospheric drought at Újfehértó (1989-2011)

Regarding the indices of changing atmospheric drought (Figure 3) we concluded that atmospheric drought diminished until the beginning of the 80-es years but increased from 1983 until the present time. Between 1982 and 1985 we found yearly 6-8 days with high atmospheric drought. At present, the incidents of severe drought increased to 16-18 days per season. If this tendency continues, we should prepare ourselves to even more days. Those results are conform with the opinions of other Hungarian authors (Mika 1988, Szász 1993, Lambert-Tölgyesi 1993), in other words we should prepare us for more dry seasons in the following decennia

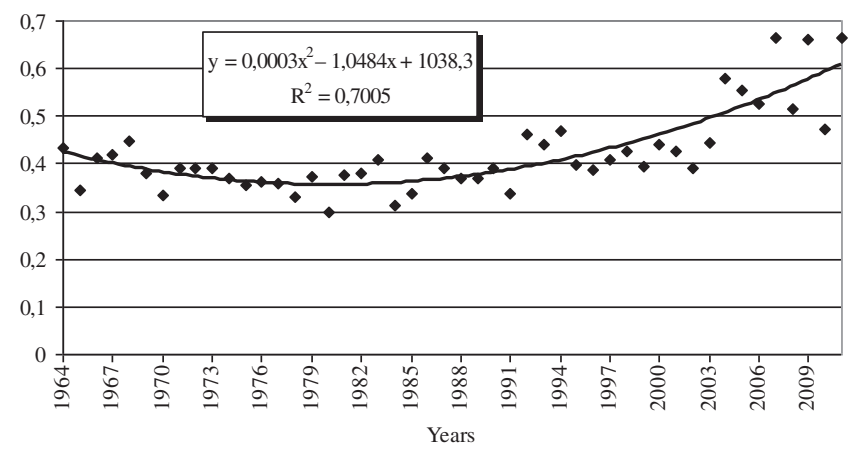

Figure 3 - The chronology of the seasonal means of atmospheric drought at Újfehértó (1964-2011)

\section{Conclusions}

The index of atmospheric drought is suitable for the purpose to (predict) estimate the yields of sour cherry, because the index LSZI signalise the reduction of the yield expected. The relation between atmospheric drought and yield cannot be mad more significant because every kind of intervention, irrigation and other tools of phytotechnology may diminish the deleterious effects of weather. The comparison with other indices of drought, the LSZI proved to be sufficiently adequate to use it for practical purposes. The index signalises the measure as well as the time span of the drought period. By computing the daily values, the whole season is adequately characterised and offers a valid tool for planning and for daily decisions in management of irrigation and for estimation and modelling of yields.

\section{Acknowledgement}

This study is funded by TECH_08-A3/2-2008-0373 and TECH_08-A4/2-2008-0138 projects.

\section{References}

Antal E. (1968): Új módszer a potenciális evapotranszspiráció számítására. Beszámolók 1967 pp. 414-430.

Antal E. \& Glantz M.H. (1988): Identifying and coping with extreme meteorological events. Published by the Hungarian Meteorologycal Service, Budapest

Bussay A., Szinell Cs. \& Szentimrei T. (1999): Az aszály magyarországi előfordulásának vizsgálata és mérhetősége. Éghajlati és Agrometeorológia tanulmányok 7: 6-55. OMSZ, Budapest

Faragó T., Kozma E. \& Nemes Cs. (1989): Drough indices in meteorology. Időjárás. 93: 45-60.

Karácsonyi Z. (1994): Légköri környezet módosítása alacsony intenzitású esőztetéssel. Kandidátusi értekezés. Debrecen, 1-105. p. 
Lakatos L., Karácsonyi Z., Racskó J., Sun Zhong-Fu \& Wang Yingchun (2005): A légköri szárazság hatásának vizs-gálata a különböző kertészeti és szántóföldi növényfajok termésmennyiségének változására Agrártudományi közlemények, 18.

Lambert K \& Tölgyesi L. (1993): Az éghajlati változékonyság hatása a vegetációs periódus meteorológia viszonyaira. OMSZ Hiv. Kiadv. 59: 42-58.

Mika J. (1988): A globális felmelegedés regionális sajátosságai a Kárpát-medencében. Időjárás, 92: 178-198.

Nemes Cs. (1993): A kukorica terméseredménye és az aszály. Egyetemi doktori értekezés. ELTE TTK, Budapest, pp. 3-54.

Pálfai I. (1993): Az 1992. évi aszály értékelése az aszályossági index alapján. „Az 1992. évi aszály értékelése” c. kiadvány. Eds: Pálfai I., Vermes L. FM, MAE, MHT, Budapest, pp. 25-28.

Pálfai I., Boga T.L. \& Sebesvári J. (1999): Adatok a magyarországi aszályokról 1931-1998. Éghajlati és Agrometeorológia tanulmányok 7: 67-91. OMSZ, Budapest
Palmer, W. C. (1965): Meteorological drought. US Weather Bureau., Res Paper No. 45: 1-58. Washington DC.

Simon M. (1993): A Pálfai-féle aszályossági index gyakorlati alkalmazhatósága. Acta Geografica Debrecina 1991-1992 Tomus 30-31: 283-307. Debrecen,

Szász G. (1973): A potenciális párolgás meghatározásának új módszere. Hidrológiai Közlöny, pp. 434-442.

Szász G. (1993): Az éghajlatváltozás szerepe a növénytermesztés stratégiájában. OMSZ Hiv. Kiadv. 59: 9-23.

Varga-Haszonits Z. (1989): A vegetációs periódus alati vízellátottság mértékének éghajlati jellemzői. „Aszály” c. kiadvány, Ed.: Hanyecz Vince, Öntözési Kut. Int. Szarvas, pp. 28-41.

Varga-Haszonits Z. \& Tólgyesi L. (1990): Alapvető agroklimatológia jellemzoértékek meghatározása, Agroökológia Információs Rendszer Program (Tanulmány) 